\title{
Quality of goat's milk produced on farms in the Paraná State - Brazil
}

\section{Qualidade do leite de cabra produzido em fazendas do Paraná - Brasil}

\author{
Edson Antonio Rios ${ }^{1 *}$; Juliana Ramos Pereira ${ }^{1}$; Ronaldo Tamanini ${ }^{2}$; Juliana \\ Mareze $^{3}$; Natalia Gonzaga ${ }^{3}$; Eric Ossugui ${ }^{4}$; Luís Augusto Nero ${ }^{5}$; Vanerli Beloti ${ }^{6}$
}

\begin{abstract}
The consumption of goat's milk has increased significantly in Brazil. In 2014, its production was 153 thousand tons, and the Paraná state is responsible for the production of 380 thousand liters. Although the government regulates goat milk, this raw material is not widely studied in Brazil. The objective of this work was to study its microbiological and physicochemical characteristics. A total of 32 samples from 8 Paraná State farms were analyzed. The microbial indicators of hygiene, psychrotrophic bacteria, $L$. monocytogenes and Salmonella spp. were evaluated. We used physicochemical tests of goat's milk that were established by the Brazilian legislation. In addition, phosphatase activity, $\mathrm{pH}$, conductivity, boiling test, and urea content were measured. The average concentrations of mesophilic aerobes, coliforms, $E$. coli, coagulase positive Staphylococcus and psychrotrophic microorganisms were 4.10, 2.38, 0.65, 2.06 and $4.02 \log$ CFU mL $\mathrm{mL}^{-1}$, respectively. The samples did not present L. monocytogenes and Salmonella spp. In the physicochemical analysis, $90.63 \%$ of the samples presented at least one parameter outside the legal standards. In the somatic cell count, $73.33 \%$ of the samples had counts higher than $1 \times 10^{6}$ cells $\mathrm{mL}^{-1}$. Raw goat's milk produced in Paraná has high coliform and psychrotrophic counts, indicating poor hygiene during milking. The fluctuating values of the physicochemical data indicate that additional studies are required to determine the parameters that reflect the Brazilian conditions of goat milk production.
\end{abstract}

Key words: Pathogenic bacteria. SCC. Legislation.

\section{Resumo}

O consumo de leite de cabra tem aumentado significativamente no Brasil. Em 2014, sua produção foi de 153 mil toneladas, e o estado do Paraná foi responsável pela produção de 380 mil litros. Embora o governo regulamenta o leite de cabra, essa matéria-prima não é amplamente estudada no Brasil. $\mathrm{O}$ objetivo deste trabalho foi estudar suas características microbiológicas e físico-químicas. Foram analisadas 32 amostras de 8 fazendas do estado do Paraná. Os indicadores microbianos de higiene,

1 Discentes, Curso de Pós-Graduação em Ciência Animal, Universidade Estadual de Londrina, UEL, Londrina, PR, Brasil. E-mail: edsonrios1@hotmail.com; julianapereira.mv@hotmail.com

2 Médico Veterinário, Dr., UEL, Londrina, PR, Brasil. E-mail: ronaldot@uel.br

3 Discentes, Curso de Residência em Inspeção de Leite e Derivados, UEL, Londrina, PR, Brasil. E-mail: juliana_mareze@hotmail. com; natalia_gonzaga_@hotmail.com

4 Discente, Curso de Graduação em Medicina Veterinária, Bolsista de Iniciação Científica, UEL, Londrina, PR, Brasil. E-mail: eric.ossugui@hotmail.com

5 Prof. Dr., Departamento de Medicina Veterinária, Universidade Federal de Viçosa, UFV, Viçosa, MG, Brasil. E-mail: nero@ufv.br

6 Prof $^{\mathrm{a}} \mathrm{Dr}^{\mathrm{a}}$, Departamento de Medicina Veterinária Preventiva, UEL, Londrina, PR, Brasil. E-mail: vbeloti@uel.br

* Author for correspondence 
bactérias psicrotróficas, L. monocytogenes e Salmonella spp. foram avaliados. Foram realizados testes físico-químicos estabelecidos pela legislação brasileira para leite de cabra. Além disso, realizou-se o teste de ebulição e o teor de ureia. As concentrações médias de aeróbios mesofílicos, coliformes, $E$. coli, Staphylococcus coagulase positivo e microrganismos psicrotróficos foram de 4.10, 2.38, 0.65, 2.06 e $4.02 \log$ UFC mL $\mathrm{mL}^{-1}$, respectivamente. As amostras não apresentaram L. monocytogenes e Salmonella spp. $\mathrm{Na}$ análise físico-química, $90.63 \%$ das amostras apresentaram pelo menos um parâmetro fora dos padrões legais. Na contagem de células somáticas, $73.33 \%$ das amostras tiveram contagens superiores a $1 \times 10^{6}$ células $\mathrm{mL}^{-1}$. O leite de cabra cru produzido no Paraná tem altas contagens de coliformes e psicrotróficos, indicando uma má higiene durante a ordenha. Os valores flutuantes dos dados físicoquímicos indicam que são necessários estudos adicionais para determinar os parâmetros que refletem as condições brasileiras de produção de leite caprino.

Palavras-chave: Bactérias patogênicas. CCS. Legislação.

\section{Introduction}

According to the Food and Agriculture Organization of the United Nations (FAO), the Brazilian goat milk production was 153 thousand tons in 2014 (FAO, 2014). The Paraná State contributed 380 thousands liters, and the majority of the goat milk was used to produce cheese and frozen milk (CORDEIRO, 2014).

In Brazil, goat milk is a growing business because of its nutritional characteristics and associated technology. Mainly due to its potential hypoallergenic properties, goat milk is preferred compared to cow milk. The flavor and texture of goat milk have also been explored to make various products such as new varieties of cheese and yoghurt (MEDINA; NUÑEZ, 2004; SCINTU; PIREDDA, 2007).

The increase in goat milk consumption prompted the Brazilian Agriculture Ministry to establish specific rules for goat milk production in 2000, aiming to improve its quality based on animal health, milking procedures, storage, transport, and processing conditions (BRASIL, 2000). Although new legislation has been created specifically for goat milk, the hygienic and sanitary conditions that are present during milking and milk storage in Brazil are not as well known as the microbiology and physicochemical characteristics. Accordingly, the present study aimed to characterize the microbiology and physicochemical properties of goat milk produced in Paraná State.

\section{Material and Methods}

Samples

Eight goat farms in Paraná State (Brazil) were selected, and they are responsible for producing $23.45 \%$ of the goat milk in the State (IBGE, 2006) (Table 1). Raw goat milk samples $(n=32)$ were collected immediately after milking using sterile utensils. The samples were collected in four replicates: each one in one season of the year. Raw goat milk samples were transported under refrigeration until analysis. 
Table 1. Main production characteristics of eight goat farms in Paraná State and number of samples collected for the present study, between October 2013 and August 2014.

\begin{tabular}{ccccccc}
\hline $\begin{array}{c}\text { Farm } \\
(\text { City) }\end{array}$ & $\begin{array}{c}\text { Goat } \\
\text { Breed }\end{array}$ & $\begin{array}{c}\text { Lactating } \\
\text { animals (n)* }\end{array}$ & $\begin{array}{c}\text { Daily milk } \\
\text { production } \\
(\mathbf{L}) *\end{array}$ & $\begin{array}{c}\text { Milking sys- } \\
\text { tem }\end{array}$ & $\begin{array}{c}\text { Storage sys- } \\
\text { tem }\end{array}$ & $\begin{array}{c}\text { Number of } \\
\text { sample (n) }\end{array}$ \\
\hline A & $\begin{array}{c}\text { Saanen/An- } \\
\text { glo-Nubian }\end{array}$ & 42 & 53 & Handmade & Freezing & 4 \\
B & Saanen & 48 & 75 & Automatic & Bulk tank & 4 \\
C & Saanen & 7 & 18 & Handmade & Refrigerator & 4 \\
D & Mixed & 8 & 18 & Handmade & Refrigerator & 4 \\
E & Mixed/Saanen & 5 & 12 & Handmade & Freezing & 4 \\
F & Saanen & 11 & 16 & Automatic & Freezing & 4 \\
G & Saanen & 50 & 26 & Automatic & Bulk tank & 4 \\
H & Saanen & 11 & 19 & Automatic & Freezing & 4 \\
\hline
\end{tabular}

${ }^{*}$ Approximate value, based on records during sampling.

\section{Microbiological analysis}

Mesophilic aerobes were enumerated using Petrifilm $^{\mathrm{TM}}$ AC (3M Microbiology, Minnesota, USA), and coliforms and Escherichia coli were eumerated in Petrifilm ${ }^{\mathrm{TM}}$ EC (3M Microbiology, Minnesota, USA) according to the manufacturer's instructions. Coagulase-positive Staphylococcus were enumerated following the ISO 6888-2 (1999) instructions in Baird Parker Agar Base supplemented with RPF (RabbitPlasma Fibrinogen). Psychrotrophics were enumerated according to Wehr and Frank (2004), and they were plated in surface plate count agar followed by incubation at $7^{\circ} \mathrm{C}$ for 10 days. For all these microbiology analyses, the samples were diluted ten-fold using $0.85 \% \mathrm{NaCl}$ and $0.1 \%$ peptone, and the final results were expressed as colony forming units per $\mathrm{mL}^{-1}$ (CFU mL ${ }^{-1}$ ).

The survey of Salmonella spp. was accomplished according to ISO 6579 (2002) and Listeria monocytogenes according to procedures established by the Bacterial Analytical Manual/Food and Drug Administration (BAM/FDA) (HITCHINS, 2003).

\section{Physicochemical analyses}

The Dornic acidity and density were conducted according to Instrução Normativa 68 (IN 68), Brazilian legislative (BRASIL, 2006). The freezing point was analyzed by digital cryoscopy PZL ${ }^{\circledR} 7000$ (PZL, Paraná, Brazil) performed in accordance with the manufacturer's instructions. The boiling milk test was conducted to determine the milk stability. Two milliliters was boiled in a test tube, and if coagulation occurred, the sample was considered instable (JURJEN et al., 2009).

The measurements of fat, protein, lactose and total solids were conducted in the infrared analyzer Bentley $2000^{\circledR}$ (Bentley instruments Inc., Minnesota, USA). The urea content was determined according to the enzymatic method in the Chemspec $150^{\circledR}$ (Bentley instruments Inc., Minnesota, USA), and somatic cell counts (SCCs) were measured in a Somacount $500^{\circledR}$ (Bentley instruments Inc., Minnesota, USA) that utilizes laser-based flow cytometry. All those analyses were conducted in the laboratory of Associação Paranaense de Criadores de Bovinos da Raça Holandesa (APCBRH) that is part of the Network Brazilian Milk Quality. All instruments used were calibrated for goat milk. 


\section{Statistical analyses}

All microbiological counts were converted to $\log _{10}$ and mean values were compared by ANOVA to identify significant differences between seasons $(p<0.05)$. Statistical analyses were performed using the SPSS 24.0 statistical analysis system (SPSS Inc., Illinois, USA).

\section{Results and Discussion}

The goat milk samples presented a mean count of mesophilic aerobes of $4.10 \log \mathrm{CFU}$ $\mathrm{mL}^{-1}$ (Figure 1). The mesophilic aerobes are used as a microbiological parameter by the Brazilian legislature with a limit of $5.70\left(5 \times 10^{5}\right) \log \mathrm{CFU}$
$\mathrm{mL}^{-1}$ (BRASIL, 2000). According to this guideline, four samples would be considered irregular. However, counts higher than $5.00 \log \mathrm{CFU} \mathrm{mL} \mathrm{m}^{-1}$ for mesophilic aerobes are indicative of hygiene failure during milk production (CHAMBERS, 2002). Thus, in 12/32 samples (37.50\%), hygiene problems were observed in obtaining the milk. These results are also in accordance with similar study on raw goat milk from Minas Gerais - Brazil (YAMAZI et al., 2013). However, Oliveira et al. (2011) reported that $62.50 \%$ of the samples exceeded the values of $5 \mathrm{log}$ in raw goat milk produced in Northeast Brazil. In our study, only two of the farms (D and E), all the samples presented values lower than $5.00 \log$ CFU $\mathrm{mL}^{-1}$.

Figure 1. The box plot shows the microbiological count distributions performed in 32 raw goat milk samples from eight Paraná State (Brazil) farms (values in $\log _{10} \mathrm{CFU} / \mathrm{mL}^{-1}$ ), collected between October 2013 and August 2014.

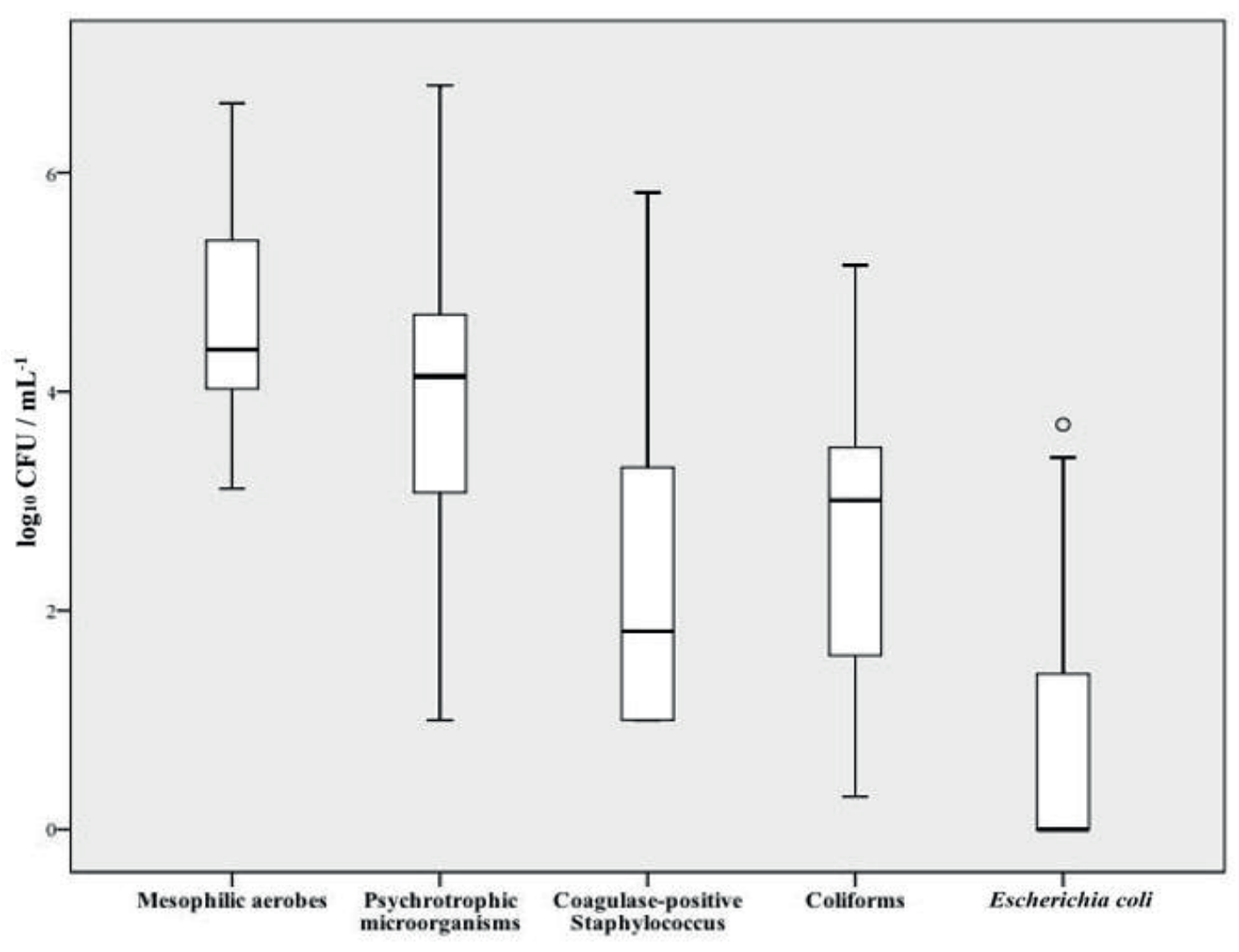


Coliforms and E. coli are good indicators of the hygienic-sanitary quality for food. Coliforms indicate environmental contamination, and E. coli indicates fecal contamination and the possible risk of the presence of other pathogenic microorganisms (GOTTARDI et al., 2008). In the present study, all samples had coliforms counts ranging from 0.30 $\log$ to $5.60 \log \mathrm{CFU} \mathrm{mL} \mathrm{m}^{-1}$ (Figure 1), and 16/32 samples $(50.00 \%)$ presented counts higher than $3.00 \log$ CFU mL $\mathrm{mL}^{-1}$ which, according to Martins and Lima (2013), represents poor hygienic and sanitary conditions during milking. The presence of $E$. coli was detected in 10/32 samples (31.25\%), and it was not detected on the $\mathrm{E}$ and $\mathrm{H}$ farms $(6.25 \%)$.

Staphylococci are important indicators of the quality of food handling because they are natural inhabitants of human and animal skin as well as the main etiological agents of bovine mastitis. In this study, the mean coagulase-positive Staphylococcus count was $2.06 \log \mathrm{CFU} \mathrm{mL} \mathrm{m}^{-1}$. These results were lower than those found in the Northeast of Brazil (6.29 $\log$ CFU mL $\mathrm{m}^{-1}$ ) by Oliveira et al. (2011). Foods with counts above $5.00 \log \mathrm{CFU} \mathrm{mL} \mathrm{mL}^{-1}$ are considered to be potentially capable of causing intoxication (FORSYTHE; HAYES, 2010), which was the case in one sample $(3.13 \%)$. However, the prolonged storage of the raw milk under refrigeration can aggravate this because some strains of the genus Staphylococcus have the capacity to grow at $7^{\circ} \mathrm{C}$ (LE LOIR et al., 2003).

Brazilian legislation has not established a standard for psychrotrophic microorganisms, but with the obligatory cooling of the milk soon after milking, the growth conditions for these microorganisms are favored. In our study, the mean of psychrotrophs was $4.02 \log \mathrm{CFU} \mathrm{mL} \mathrm{mL}^{-1}$, which was lower than the count of the mesophilic aerobes
(4.10 $\log \mathrm{CFU} \mathrm{mL}-1$ ), a result similar to that found in Minas Gerais, Brazil by Yamazi et al. (2013) (4.10 $\left.\log \mathrm{CFU} \mathrm{mL}^{-1}\right)$. However, 10/32 samples (31.25\%) had psychrotrophic counts higher than those of mesophilic aerobes. In the case of prolonged cooling, this proportion could be higher because the multiplication of mesophilic aerobes is reduced under refrigeration, whereas the multiplication of psychrotrophs is favored - a situation that was not observed in this study because the samples were collected shortly after milking. This indicates that the natural microbiota of one-third of goat's milk produced in Paraná is predominantly psychrotrophic. The psychrotrophic bacteria have great importance in the quality of the milk because many of these microorganisms produce lipolytic and proteolytic enzymes, which contribute to the progressive degradation of proteins and lipids, not only during storage but also after the heat treatment because they are thermostable enzymes (RAYNALLJUTOVAC et al., 2005).

Salmonella spp. and Listeria monocytogenes were not detected in any of the analyzed samples, which is a result similar to that found in Greece, Portugal and France (MORGAN et al., 2003). Although there are not many studies on the presence of Salmonella spp. and Listeria monocytogens in raw goat's milk in Brazil, Oliveira et al. (2011) detected Salmonella enterica in 2/96 samples (2.08\%), and they did not detect Listeria monocytogenes. In cow's milk, studies show that the absence of pathogens in raw milk is related to microbial competition, mainly promoted by lactic acid bacteria (NERO et al., 2008; MATTOS et al., 2010).

No significant difference $(\mathrm{p}>0.05)$ was found between the counts of the microorganisms surveyed when related to the season (Figure 2). 
Figure 2. Means of counts in the four seasons for microorganisms ( $\left.\log \mathrm{CFU} / \mathrm{mL}^{-1}\right)$ investigated in 32 samples from eight farms in Paraná State (Brazil), between October 2013 and August 2014.

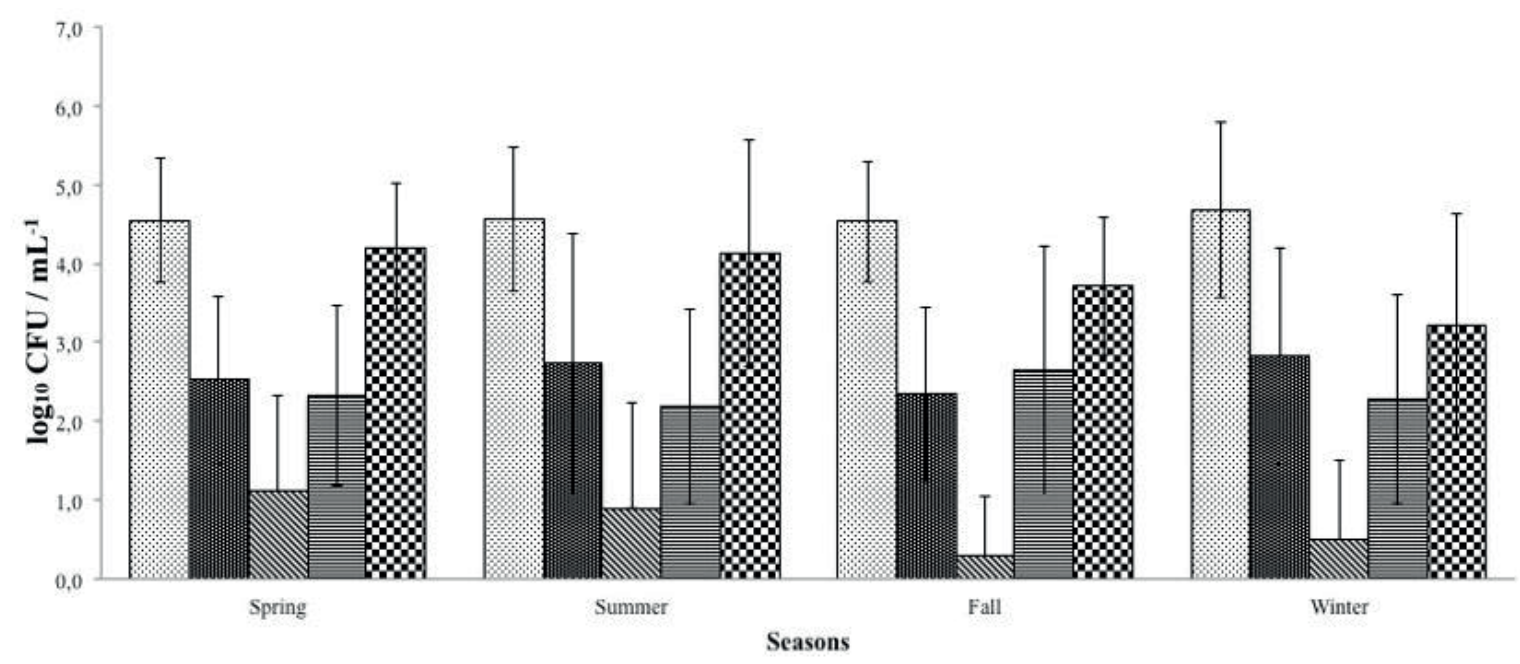

Mesophilic aerobes Coliforms $\mathbb{\Delta}$ Escherichia coli 自 Coagulase-positive Staphylacoccus Psychrotrophics

Regarding the physicochemical characteristics, determined by Brazilian legislation (BRASIL, 29/32 (90.63\%) samples presented some 2000) (Table 2 and Figure 3).

irregularities when compared to the parameters

Table 2. Mean physicochemical characteristics, standard deviation and median of 32 raw goat milk samples, collected in eight Paraná State farms from October 2013 to August 2014, and standards determined by Brazilian legislation.

\begin{tabular}{|c|c|c|c|c|c|c|c|c|c|c|}
\hline & $\begin{array}{l}\text { Stan- } \\
\text { dards }{ }^{1}\end{array}$ & $\mathbf{A}$ & B & $\mathbf{C}$ & D & $\mathbf{E}$ & $\mathbf{F}$ & G & $\mathbf{H}$ & $\begin{array}{c}\text { General } \\
\text { mean }\end{array}$ \\
\hline $\begin{array}{l}\text { Density } \\
\left(\mathrm{g} \mathrm{mL}^{-1}\right)\end{array}$ & $\begin{array}{l}1.028 \\
\text { to } \\
1.034\end{array}$ & $\begin{array}{c}1.030 \\
\pm 0.001\end{array}$ & $\begin{array}{c}1.030 \\
\pm 0.005\end{array}$ & $\begin{array}{c}1.030 \\
\pm 0.002\end{array}$ & $\begin{array}{c}1.031 \\
\pm 0.004\end{array}$ & $\begin{array}{c}1.030 \\
\pm 0.001\end{array}$ & $\begin{array}{c}1.030 \\
\pm 0.001\end{array}$ & $\begin{array}{c}1.031 \\
\pm 0.001\end{array}$ & $\begin{array}{c}1.030 \\
\pm 0.001\end{array}$ & $\begin{array}{c}1.030 \\
\pm 0.002\end{array}$ \\
\hline $\begin{array}{c}\text { Freezing } \\
\text { point } \\
\left({ }^{\circ} \mathbf{H}\right)\end{array}$ & $\begin{array}{l}-0.550 \\
\text { to } \\
-0.580\end{array}$ & $\begin{array}{l}-0.558 \\
\pm 0.011\end{array}$ & $\begin{array}{l}-0.561 \\
\pm 0.012\end{array}$ & $\begin{array}{l}-0.568 \\
\pm 0.005\end{array}$ & $\begin{array}{l}-0.565 \\
\pm 0.006\end{array}$ & $\begin{array}{l}-0.564 \\
\pm 0.009\end{array}$ & $\begin{array}{l}-0.567 \\
\pm 0.005\end{array}$ & $\begin{array}{l}-0.547 \\
\pm 0.023\end{array}$ & $\begin{array}{l}-0.563 \\
\pm 0.006\end{array}$ & $\begin{array}{l}-0.562 \\
\pm 0.012\end{array}$ \\
\hline $\begin{array}{l}\text { Dornic } \\
\text { Acidity } \\
\text { ('D) }\end{array}$ & 13 to $18^{2}$ & $\begin{array}{l}19.00 \\
\pm 1.40\end{array}$ & $\begin{array}{l}15.50 \\
\pm 2.60\end{array}$ & $\begin{array}{l}19.00 \\
\pm 2.20\end{array}$ & $\begin{array}{l}21.00 \\
\pm 3.50\end{array}$ & $\begin{array}{l}18.50 \\
\pm 4.40\end{array}$ & $\begin{array}{l}18.00 \\
\pm 3.00\end{array}$ & $\begin{array}{l}19.00 \\
\pm 2.20\end{array}$ & $\begin{array}{l}16.80 \\
\pm 1.30\end{array}$ & $\begin{array}{l}18.30 \\
\pm 2.90\end{array}$ \\
\hline $\begin{array}{l}* \text { Fat } \\
(\%)\end{array}$ & $\begin{array}{l}\text { Original } \\
\text { fat con- } \\
\text { tent }^{3}\end{array}$ & $\begin{array}{c}3.96 \\
\pm 0.48\end{array}$ & $\begin{array}{c}2.81 \\
\pm 0.56\end{array}$ & $\begin{array}{c}4.02 \\
\pm 0.80\end{array}$ & $\begin{array}{c}3.68 \\
\pm 1.30\end{array}$ & $\begin{array}{c}4.35 \\
\pm 0.67\end{array}$ & $\begin{array}{c}3.34 \\
\pm 0.39\end{array}$ & $\begin{array}{c}4.58 \\
\pm 0.23\end{array}$ & $\begin{array}{c}3.58 \\
\pm 0.93\end{array}$ & $\begin{array}{c}3.84 \\
\pm 0.84\end{array}$ \\
\hline $\begin{array}{c}* \text { Protein } \\
(\%)\end{array}$ & $\begin{array}{l}\text { Minimum } \\
\text { of } 2.8\end{array}$ & $\begin{array}{c}3.31 \\
\pm 0.25\end{array}$ & $\begin{array}{c}3.03 \\
\pm 0.52\end{array}$ & $\begin{array}{c}3.33 \\
\pm 0.38\end{array}$ & $\begin{array}{c}3.79 \\
\pm 0.46\end{array}$ & $\begin{array}{c}3.55 \\
\pm 0.53\end{array}$ & $\begin{array}{c}3.22 \\
\pm 0.24\end{array}$ & $\begin{array}{c}3.69 \\
\pm 0.45\end{array}$ & $\begin{array}{c}3.07 \\
\pm 0.24\end{array}$ & $\begin{array}{c}3.39 \\
\pm 0.44\end{array}$ \\
\hline
\end{tabular}


continuation

\begin{tabular}{|c|c|c|c|c|c|c|c|c|c|c|}
\hline $\begin{array}{c}* \text { Lac- } \\
\text { tose } \\
(\%)\end{array}$ & $\begin{array}{c}\text { Minimum } \\
\text { of } 4.3\end{array}$ & $\begin{array}{c}4.39 \\
\pm 0.15\end{array}$ & $\begin{array}{c}4.16 \\
\pm 0.17\end{array}$ & $\begin{array}{c}4.07 \\
\pm 0.13\end{array}$ & $\begin{array}{c}4.79 \\
\pm 0.24\end{array}$ & $\begin{array}{c}4.43 \\
\pm 0.23\end{array}$ & $\begin{array}{c}4.14 \\
\pm 0.07\end{array}$ & $\begin{array}{c}4.24 \\
\pm 0.05\end{array}$ & $\begin{array}{c}4.22 \\
\pm 0.22\end{array}$ & $\begin{array}{c}4.31 \\
\pm 0.27\end{array}$ \\
\hline $\begin{array}{c}* \text { Total } \\
\text { solids } \\
(\%)\end{array}$ & -4 & $\begin{array}{l}12.67 \\
\pm 0.87\end{array}$ & $\begin{array}{c}10.9 \\
\pm 0.79\end{array}$ & $\begin{array}{l}12.46 \\
\pm 1.03\end{array}$ & $\begin{array}{l}13.31 \\
\pm 1.85\end{array}$ & $\begin{array}{l}13.41 \\
\pm 1.22\end{array}$ & $\begin{array}{l}11.65 \\
\pm 0.72\end{array}$ & $\begin{array}{l}13.57 \\
\pm 0.50\end{array}$ & $\begin{array}{l}11.83 \\
\pm 1.29\end{array}$ & $\begin{array}{l}12.56 \\
\pm 1.31\end{array}$ \\
\hline $\begin{array}{c}* \text { SNF } \\
(\%)\end{array}$ & 8.2 & $\begin{array}{c}8.72 \\
\pm 2.28\end{array}$ & $\begin{array}{c}8.14 \\
\pm 0.43\end{array}$ & $\begin{array}{c}8.45 \\
\pm 0.29\end{array}$ & $\begin{array}{c}9.63 \\
\pm 0.76\end{array}$ & $\begin{array}{c}9.07 \\
\pm 0.56\end{array}$ & $\begin{array}{c}8.31 \\
\pm 0.34\end{array}$ & $\begin{array}{c}8.99 \\
\pm 0.43\end{array}$ & $\begin{array}{c}8.25 \\
\pm 0.40\end{array}$ & $\begin{array}{c}8.73 \\
\pm 0.64\end{array}$ \\
\hline $\begin{array}{c}{ }^{*} \text { Urea } \\
(\mathrm{mg} \\
\left.\mathrm{dL}^{-1}\right)\end{array}$ & - & $\begin{array}{l}18.18 \\
\pm 2.28\end{array}$ & $\begin{array}{c}23.76 \\
\pm 13.13\end{array}$ & $\begin{array}{l}22.87 \\
\pm 0.75\end{array}$ & $\begin{array}{l}19.96 \\
\pm 5.30\end{array}$ & $\begin{array}{l}19.43 \\
\pm 3.53\end{array}$ & $\begin{array}{l}27.03 \\
\pm 2.56\end{array}$ & $\begin{array}{c}33.45 \\
\pm 7.1\end{array}$ & $\begin{array}{c}28.32 \\
\pm 10.97\end{array}$ & $\begin{array}{l}24.00 \\
\pm 7.83\end{array}$ \\
\hline
\end{tabular}

${ }^{1}$ According to Brazilian legislation (BRASIL, 2000).

${ }^{2}$ The normal range for the titratable acidity of frozen goat's raw milk will vary from 11 to $18^{\circ} \mathrm{D}$ (BRASIL, 2000).

${ }^{3}$ Values of less than $2.9 \%$ will be admitted, proving that the average fat content of a given herd does not reach that level (BRASIL, 2000).

${ }^{4}$ Standard not established (BRASIL, 2000).

*Analysis of 30 samples. Samples G and H were analyzed in three replicates for these components.

Figure 3. Percentages of physicochemical changes, in disagreement with Brazilian legislation, detected in 32 raw goat milk samples produced in the Paraná State farms (Brazil).

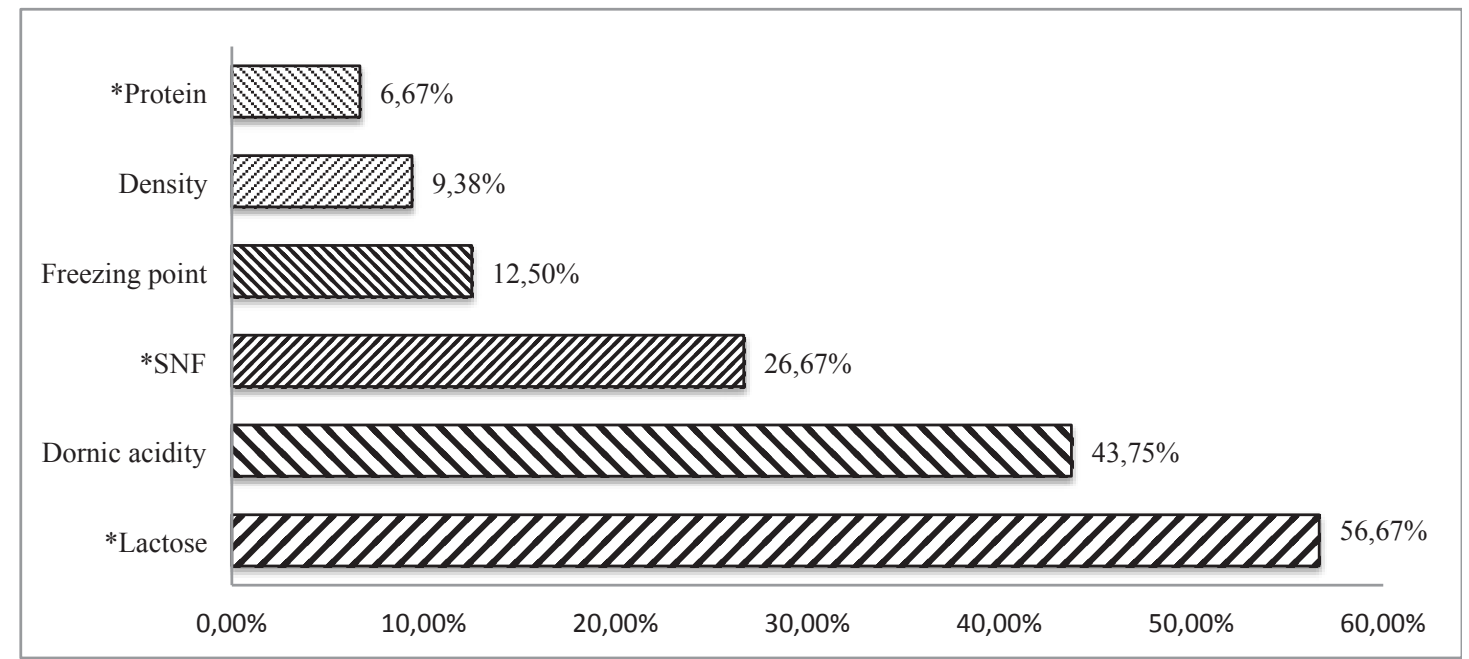

*Analysis of 30 samples. Samples G and H were analyzed in three replicates for these components.

The average for the Dornic acidity was $18.30^{\circ} \mathrm{D}$, with values of 13 to $25^{\circ} \mathrm{D}$. The standard established by the legislation is $13-18^{\circ} \mathrm{D}$ (BRASIL, 2000). In $14 / 32$ samples $(43.75 \%)$ analyzed, the values were higher than $18^{\circ} \mathrm{D}$ indicating high microbial contamination, and this was confirmed by the mesophilic aerobes, four of which were above $5.7 \log \mathrm{CFU} \mathrm{mL}^{-1}$, which is the legal standard
(BRASIL, 2000). Mesophilic aerobes preferentially have saccharolytic metabolism, and they rapidly degrade lactose, leading to the formation of lactic acid (GOTTARDI et al., 2008).

The general mean for density was $1.030 \mathrm{~g} \mathrm{~mL}^{-}$ ${ }^{1}$, ranging from $1.024-1.036 \mathrm{~g} \mathrm{~mL}^{-1}$, and $3 / 32$ samples $(9.38 \%)$ presented a non-standard result established by the legislation (BRASIL, 2000): 
farms B (1.024 and $\left.1.036 \mathrm{~g} \mathrm{~mL}^{-1}\right)$ and $\mathrm{D}(1.036 \mathrm{~g}$ $\left.\mathrm{mL}^{-1}\right)$. The sample of farm $\mathrm{B}$, which had a density of $1.024 \mathrm{~g} \mathrm{~mL}^{-1}$, also had a freezing point value $(-0.546$ $\left.{ }^{\circ} \mathrm{H}\right)$ lower than that determined by legislation, which was indicative of the presence of water and could have been intentional or accidental residue from the mechanical milking system. Although the Brazilian legislation determined the density standard of 1.028-1.034 $\mathrm{g} \mathrm{mL}^{-1}$ (BRASIL, 2000), research in other countries has shown that the density of goat milk can vary from 1.029 to 1.039 $\mathrm{g} \mathrm{mL}^{-1}$ and can be affected by seasonal influences, animals' physiological state and breed (PARK et al., 2007). In our study, the milking of the animals was accompanied, thus excluding intentional fraud, by adding water and reconstitution of the samples that presented values higher than $1.034 \mathrm{~g} \mathrm{~mL}^{-1}$, suggesting that the samples with values higher than $1.034 \mathrm{~g} \mathrm{~mL}^{-1}$ exhibited natural variations, thus confirming the need for further studies to evaluate the baseline parameters of goat milk produced in Brazil. The freezing point values were -0.516 to $-0.573^{\circ} \mathrm{H}$, and the mean was $-0.562^{\circ} \mathrm{H}$, which is within the range of established values for goat milk (Table 2) (BRASIL, 2000). Other researchers observed mean freezing point values that were similar to the values observed in this study: Andrade et al. (2008) detected $-0.553^{\circ} \mathrm{H}$ in Minas Gerais, and Prata et al. (1998) observed $-0.574^{\circ} \mathrm{H}$ in southeastern Brazil. Mayer and Fiechter (2012) in Austria observed an average value that was lower than what has been reported in Brazil $\left(-0542^{\circ} \mathrm{H}\right)$. The freezing milk test is a high sensitivity test to determine the presence of water in milk (SLAGHUIS, 2001). However, this parameter is influenced by breed, stage and lactation number, occurrence of subclinical mastitis, nutritional deficiencies, water intake, climatic conditions, thermal stress, seasonal influences, presence of $\mathrm{CO}_{2}$ in milk, and regional variations (JANŠTOVÁ et al., 2007). In this study, four samples of three different farms presented values below $-0.550^{\circ} \mathrm{H}$, A $\left(-0.544^{\circ} \mathrm{H}\right), \mathrm{B}\left(-0.546^{\circ} \mathrm{H}\right)$ and $\mathrm{H}\left(-0.543\right.$ and $\left.-0.516^{\circ} \mathrm{H}\right)$. Three samples presented values very close to the standard. However, due to the various factors that could influence the freezing point, other studies of normal freezing point values in the Paraná State are necessary. Farms B and H had a mechanical milking system, which, due to equipment problems, could allow residual water to pass into the milk.

Goat milk presents lower thermal stability because of the formation of micelles, and it has higher inorganic calcium and phosphorus concentrations than milk of bovine origin (JENNESS, 1980). Therefore, Brazilian legislation (BRASIL, 2000) does not recommend the alizarol test to verify the thermal stability of goat milk. In this study, we verified the thermal stability using the boiling test, where all the samples were stable, demonstrating that this test could be an alternative to the test that is commonly used in industry.

Five samples from four different farms had fat values lower than $3.00 \%$, which is the value determined by legislation, although the average value $(3.84 \%)$ was in agreement with the value of $3.80 \%$ for goat milk as described in the literature (PARK et al., 2007). However, fat is influenced by many factors including season, stage of lactation, breed, and type of feeding (SCINTU; PIREDDA, 2007).

The milk from two farms had values lower than $2.80 \%$, which is the minimum level of protein established by the legislation: farm B $(2.50 \%)$ and $\mathrm{H}(2.73 \%)$. However, the mean was $3.39 \%$, a result close to that observed in other studies by Kondyli et al. (2012) in Greece, by Morgan et al. (2003) in France, by Prata et al. (1998) in Southeast Brazil and by Skeie (2014) in Norway, who obtained values of $3.44 \%, 3.26 \%, 3.27 \%$ and $3.09 \%$, respectively. The protein content, similar to fat, is influenced by breed, season, genetics and diet (ILOEJE et al., 1981; PERIS et al., 1997; MORGAN et al., 2003).

The analyzed goat milk presented values of lactose ranging from 3.90 to $5.10 \%$ with a mean of $4.31 \%$. Similar results were reported by Queiroga 
et al. (2007) in northeastern Brazil, Morgan et al. (2003) in Portugal, Skeie (2014) in Norway and Prata et al. (1998) in southeastern Brazil. These studies reported values of $4.10 \%, 4.21 \%, 4.32 \%$, and $4.35 \%$, respectively. In $17 / 30$ samples (56.67\%), for eight properties, the values were lower than $4.30 \%$, which is the value established by the legislation (BRASIL, 2000). The lactose values were all higher than $4.30 \%$ for the milk from only one farm (D). Silanikove et al. (2010) reported that the desirable average amount of lactose for goat milk is $4.10 \%$. Using this value as a cutoff, five samples would still have low levels of lactose. Despite this variation, lactose is one of the most stable nutrients in the chemical composition of milk, and it is directly related to the regulation of osmotic pressure. Higher lactose production determines higher milk production (QUEIROGA et al., 2007).

Although the average representation of solidsnon-fat (SNF) was higher $(8.73 \%)$ than the $8.20 \%$ determined in the legislation (BRASIL, 2000), eight samples had lower values.

The mean value for urea was 13.36 to $40.35 \mathrm{mg}$ $\mathrm{dL}^{-1}$, with an average of $24.00 \mathrm{mg} \mathrm{dL}^{-1}$, which is lower than the value observed in Austria $(33.5 \mathrm{mg}$ $\mathrm{dL}^{-1}$ ) (MAYER; FIECHTER, 2012). However, there is no standard for the concentration of urea, which is strongly related to the protein content of the food.
The somatic cell count (SCC) is used as a quality indicator (HAENLEIN, 1996), as it is influenced by the health of the mammary gland of the animals and the factors that aid the hygiene at milking. The somatic cell counts in goats are higher than those of cows because the type of the secretion of the goat milk - apocrine - contains many cytoplasmic particles and not only leucocyte cells (HAENLEIN, 2002). In many countries, the price of milk is defined by the SCC (RAYNAL-LJUTOVAC et al., 2005). Brazil, as well as the European Union, does not yet have a parameter for SCC. Leitner et al. (2008) in Israel proposed an SCC evaluation system for the payment of raw goat milk, where they classified milk according to the following criteria: high quality $<8 \times 10^{5}$ cells $\mathrm{mL}^{-1}$, associated with infection of approximately $25 \%$ of the herd; medium quality $<1.5 \times 10^{6}$ cells $\mathrm{mL}^{-1}$, associated with infection rate between 25 and $50 \%$; low quality $>1.5 \times 10^{6}$ cells $\mathrm{mL}^{-1}$, associated with infection rate above $50 \%$ and milk containing $>3.5 \times 10^{6}$ cells $\mathrm{mL}^{-1}$, which should not be accepted for human consumption. Comparing the results with the proposed scheme, approximately $23.33 \%$ of the samples would be unfit for consumption with values higher than $3.5 \times 10^{6}$ cells $\mathrm{mL}^{-1}$ (Table 3), and according to the United States legislation, which has a standard of $1.0 \times 10^{6}$ (CHEN et al., 2010), $73.33 \%$ of the samples of this work would be outside the established parameters.

Table 3. Somatic Cell Counts (SCCs) in 30 raw goat milk samples from eight Paraná State farms (Brazil), harvested between October 2013 and August 2014.

\begin{tabular}{|c|c|c|}
\hline \multirow{2}{*}{ Somatic Cell Counts (cells mL $\mathrm{mL}^{-1}$ ) } & \multicolumn{2}{|c|}{ Sample raw goat milk } \\
\hline & $\mathrm{N}$ & $\%$ \\
\hline$<8.4 \times 10^{5}$ & 6 & 20.00 \\
\hline $8.4 \times 10^{5} \vdash 1.0 \times 10^{6}$ & 2 & 6.67 \\
\hline $1.0 \times 10^{6} \vdash 1.5 \times 10^{6}$ & 5 & 16.67 \\
\hline $1.5 \times 10^{6} \vdash 3.5 \times 10^{6}$ & 10 & 33.33 \\
\hline$\geq 3.5 \times 10^{6}$ & 7 & 23.33 \\
\hline Total & 30 & 100 \\
\hline
\end{tabular}




\section{Conclusion}

Based on the production, composition, microbiological quality and SCC, the raw goat milk produced in Paraná is low-quality. High coliform and psychrotrophic counts indicate poor hygiene at milking, although mesophilic aerobe limits have been observed in most farms.

Although $90.63 \%$ of the samples presented some physicochemical alterations, when compared with the Brazilian legislation for goat milk.

The large variation in the results of the physicochemical analyses and the impossibility of being attributed to fraudulent handling indicate that more studies are required to determine the parameters that reflect the Brazilian conditions of goat milk production. Likewise, other studies on the normal quantity of SCC in Brazilian goat milk and its relation with the presence of infections are necessary so that parameters can be established that are not yet included in the Brazilian legislation.

\section{References}

ANDRADE, P. V. D. de; SOUZA, M. R. de; PENNA, C. F. A. de M.; FERREIRA, J. M. Características microbiológicas e físico-químicas do leite de cabra submetido à pasteurização lenta pós-envase e ao congelamento. Ciência Rural, Santa Maria, v. 38, n. 5, p. 1424-1430, 2008.

BRASIL. Ministério da Agricultura, Pecuária e Abastecimento. Instrução Normativa n ${ }^{\circ} 37$, de 31/10/2000. Regulamento Técnico de Identidade e Qualidade de Leite de Cabra. Diário Oficial [da] República Federativa do Brasil, Brasília, 2000, Seção 1, p. 23-25.

Ministério da Agricultura, Pecuária e Abastecimento. Instrução Normativa $\mathrm{n}^{\circ}$ 68, de 12/12/2006. Estabelece métodos analíticos físicoquímicos oficiais para leite e produtos lácteos. Diário Oficial [da] República Federativa do Brasil, Brasília, 2006, Seção 1, p. 8.

CHAMBERS, J. V. The microbiology of raw milk. In: ROBINSON, R. K. Dairy microbiology handbook: the microbiology of milk and milk products. $3^{\text {th }}$ ed. New York: John Wiley and Sons, 2002. p. 39-90. Chapter 2.

CHEN, S. X.; WANG, J. Z.; VAN KESSEL, J. S.; REN,
F. Z.; ZENG, S. S. Effect of somatic cell count in goat milk on yield, sensory quality, and fatty acid profile of semisoft cheese. Journal of Dairy Science, Champaign, v. 93, n. 4, p. 1345-1354, apr. 2010.

CORDEIRO, P. R. C. Estudo de caso: Indústria de produtos alimentícios à base de leite de caprinos. In: I Workshop - nichos de mercado para o setor agroindustrial, 2014, Campinas. Anais... Brasilia: EMBRAPA, 2014. Available at: <https://www.embrapa.br/workshopnichos2014/ imagens/galeria/arquivos/galeria90.pdf $>$. Accessed at: 22 fev. 2017.

FOOD AND AGRICULTURE ORGANIZATION OF THE UNITED NATIONS - FAO. Livestock primary and processed. Rome: FAOSTAT-Statistics Division, 2014. Available at: $<$ http://www.fao.org/faostat/es/\# compare $>$. Accessed at: 22 feb. 2017.

GOTTARDI, C. P. T.; CARDOSO, M. M.; SCHMIDT, V. Qualidade higiênica de leite caprino por contagem de coliformes e estafilococos. Ciência Rural, Santa Maria, v. 38, n. 3 , p. $743-748,2008$.

HAENLEIN, G. F. W. Relationship of somatic cell counts in goat milk to mastitis and productivity. Small Ruminant Research, Amsterdam, v. 45, n. 2, p. 163-178, 2002.

Status and prospects of the dairy goat industry in the United States. Journal of Animal Science, Champaign, v. 74, n. 5, p. 1173-1181, 1996.

FORSYTHE, S. J.; HAYES, P. R. Food hygiene, microbiology and HACCP. $3^{\text {th }}$ ed. Maryland: Aspen, 2010. p. 21-85.

HITCHINS, A. D. Detection and enumeration of Listeria monocytogenes in foods. In: US Food and Drug Administration (FDA). Bacteriological analytical manual online. USA: FDA, 2003. Chapter 10.

ILOEJE, M. U.; VAN VLECK, L. D.; WIGGANS, G. R. Components of variance for milk and fat yields in dairy goats. Journal of Dairy Science, Champaign, v. 64, n. 11, p. 2290-2293, 1981.

INSTITUTO BRASILEIRO DE GEOGRAFIA E ESTATÍSTICA - IBGE. Censo Agropecuário. Brasília: Ministério do Planejamento, Desenvolvimento e Gestão, 2006. Available at: <http://www.ibge.gov.br/home/ pesquisa/pesquisa_google.shtm?cx $=0097910198137$ $84313549 \% 3$ Aonz63jzsr68\& cof=FORID\%3A9\&ie=I SO-8859-1\&q=leite + de + cabra + parana $\&$ sa $=$ Pesquisar $\&$ siteurl=www.ibge.gov.br\%2Fhome $\% 2$ Festatistica $\% 2 \mathrm{~F}$ economia $\% 2 \mathrm{Fagropecuaria} \% 2 \mathrm{~F}$ censoagro $\% 2 \mathrm{~F} 200$ $6 \% 2 \mathrm{Fdefaulttab}$ censoagro.shtm\&ref=www.ibge. gov.br $\% 2$ Fhome $\% 2$ Festatistica $\% 2 \mathrm{Feconomia} \% 2 \mathrm{~F}$ agropecuaria $\% 2 \mathrm{Fcensoagro} \% 2 \mathrm{~F} 2006 \% 2 \mathrm{Fdefault}$. shtm\&ss $=5043 j 1483933 j 25>$. Accessed at: 2 set. 2014. 
INTERNATIONAL

ORGANIZATION

FOR STANDARDIZATION - ISO. ISO 6579 - Microbiology of food and animal feeding stuffs - Horizontal method for the detection of Salmonella spp. Geneva: International Standardisation Organization, 2002.

ISO 6888-2 - Microbiology of food and animal feeding stuffs - Horizontal method for the enumeration of coagulase-positive staphylococci (Staphylococcus aureus and other species) - Part 2: Technique using rabbit plasma fibrinogen agar medium. Geneva: International Standardization Organization, 1999.

JANŠTOVÁ, B.; DRAČKOVÁ, M.; NAVRÁTILOVÁ, P.; HADRA, L.; VORLOVÁ, L. Freezing point of raw and heat-treated goat milk. Czech Journal Animal Science, Praga, v. 2007, n. 6215712402, p. 394-398, 2007.

JENNESS, R. Composition and characteristics of goat milk: review 1968-1979. Journal of Dairy Science, Champaign, v. 63, n. 10, p. 1605-1630, 1980.

JURJEN, D.; DUGDILL, B.; BENNETT,A.; MOUNSEY, J. Milk testing and payment systems resource book: a practical guide to assist milk producer groups. Rome: FAO, 2009. 87 p.

KONDYLI, E.; SVARNAS, C.; SAMELIS, J.; KATSIARI, M. C. Chemical composition and microbiological quality of ewe and goat milk of native Greek breeds. Small Ruminant Research, Amsterdam, v. 103, n. 2-3, p. 194-199, 2012.

LE LOIR, Y.; BARON, F.; GAUTIER, M. Staphylococcus aureus and food poisoning. Genetics and Molecular Research: GMR, Ribeirão Preto, v. 2, n. 1, p. 63-76, 2003.

LEITNER, G.; SILANIKOVE, N.; MERIN, U. Estimate of milk and curd yield loss of sheep and goats with intrammamary infection and its relation to somatic cell count. Small Ruminant Research, Amsterdam, v. 74, n. 1-3, p. 221-225, 2008.

MARTINS, E. D. S.; LIMA, C. M. F. Qualidade microbiológica de leite cru refrigerado obtido de propriedades rurais do município de Frutal-MG: Comparação das ordenhas mecânica e manual. Revista Brasileira de Tecnologia Agroindustrial, Curitiba, v. 7, n. 1, p. 955-964, 2013.

MATTOS, M. R. de; BELOTI, V.; TAMANINI, R.; MAGNANI, D. F.; NERO, L. A.; BARROS, M. D. A. F.; PIRES, E. M. F.; PAQUEREAU, B. P. D. Qualidade do leite cru produzido na região do agreste de Pernambuco, Brasil. Semina: Ciências Agrárias, Londrina, v. 31, n. 1, p. 173-181, 2010.
MAYER, H. K.; FIECHTER, G. Physical and chemical characteristics of sheep and goat milk in Austria. International Dairy Journal, Edmonton, v. 24, n. 2, p. 57-63, 2012.

MEDINA, M.; NUÑEZ, M. Cheeses made from ewes' and goats' milk. In: FOX, P. F.; MCSWEENEY, P. L. H.; COGAN, T. M.; GUINEE, T. P. Chemistry, physics and microbiology. Amsterdam: Elsevier, 2004. v. 2, p. 279299.

MORGAN, F.; MASSOURAS, T.; BARBOSA, M.; ROSEIRO, L.; RAVASCO, F.; KANDARAKIS, I.; BONNIN, V.; FISTAKORIS, M.; ANIFANTAKIS, E.; JAUBERT, G.; RAYNAL-LJUTOVAC, K. Characteristics of goat milk collected from small and medium enterprises in Greece, Portugal and France. Small Ruminant Research, Amsterdam, v. 47, n. 1, p. 3949, 2003.

NERO, L. A.; MATTOS, M. R. de; AGUIAR FERREIRA BARROS, M. de; ORTOLANI, M. B. T.; BELOTI, V.; MELO FRANCO, B. D. G. de. Listeria monocytogenes and Salmonella spp. in raw milk produced in Brazil: occurrence and Interference of indigenous microbiota in their isolation and development. Zoonoses and Public Health, Oxford, v. 55, n. 6, p. 299-305, 2008.

OLIVEIRA, C. J. B.; HISRICH, E. R.; MOURA, J. F. P.; GIVISIEZ, P. E. N.; COSTA, R. G.; GEBREYES, W. A. On farm risk factors associated with goat milk quality in Northeast Brazil. Small Ruminant Research, Amsterdam, v. 98, n. 1-3, p. 64-69, 2011.

PARK, Y. W.; JUÁREZ, M.; RAMOS, M.; HAENLEIN, G. F. W. Physico-chemical characteristics of goat and sheep milk. Small Ruminant Research, Amsterdam, v. 68, n. 1-2, p. 88-113, 2007.

PERIS, S.; CAJA, G.; SUCH, X.; CASALS, R.; FERRET, A.; TORRE, C. Influence of kid rearing systems on milk composition and yield of Murciano-Granadina dairy goats. Journal of Dairy Science, Champaign, v. 80, n. 12, p. 3249-3255, 1997.

PRATA, L. F.; RIBEIRO, A. C.; REZENDE, K. T.; CARVALHO, M. R. B.; RIBEIRO, S. D. A.; COSTA, R. G. Composição, perfil nitrogenado e características do leite caprino (saanen): região sudeste, Brasil. Ciência e Tecnologia de Alimentos, Campinas, v. 18, n. 4, p. 1-12, 1998.

QUEIROGA, R. de C. R. do E.; COSTA, R. G.; BISCONTINI, T. M. B.; MEDEIROS, A. N. de; MADRUGA, M. S.; SCHULER, A. R. P. Influência do manejo do rebanho, das condições higiênicas da ordenha e da fase de lactação na composição química do leite de cabras Saanen. Revista Brasileira de Zootecnia, Viçosa, MG, v. 36, n. 2, p. 430-437, 2007. 
RAYNAL-LJUTOVAC, K.; GABORIT, P.; LAURET, A. The relationship between quality criteria of goat milk, its technological properties and the quality of the final products. Small Ruminant Research, Amsterdam, v. 60, n. 1-2, p. 167-177, 2005.

SCINTU, M. F.; PIREDDA, G. Typicity and biodiversity of goat and sheep milk products. Small Ruminant Research, Amsterdam, v. 68, n. 1-2, p. 221-231, 2007.

SILANIKOVE, N.; LEITNER, G.; MERIN, U.; PROSSER, C. G. Recent advances in exploiting goat's milk: quality, safety and production aspects. Small Ruminant Research, Amsterdam, v. 89, n. 2-3, p. 110124, 2010.

SKEIE, S. B. Quality aspects of goat milk for cheese production in Norway: a review. Small Ruminant
Research, Amsterdam, v. 122, n. 1-3, p. 10-17, 2014.

SLAGHUIS, B. A. The freezing point of authentic and original farm bulk tank milk in The Netherlands. International Dairy Journal, Edmonton, v. 11, n. 3, p. 121-126, 2001.

WEHR, H. M.; FRANK, J. F. Standard methods. In: . Standard methods for the examination of dairy products. 17 $7^{\text {th }}$ ed. Washington: American Public Health Association, 2004. p. 227-248. Chapter 1.

YAMAZI, A. K.; MOREIRA, T. S.; CAVICCHIOLI, V. Q.; BURIN, R. C. K.; NERO, L. A. Long cold storage influences the microbiological quality of raw goat milk. Small Ruminant Research, Amsterdam, v. 113, n. 1, p. 205-210, 2013. 